\title{
Village Financial Management Toward Community Empowerment
}

\author{
Hastuti $^{1 *}$ \\ ${ }^{1}$ Department of Management, Faculty of Economics, Universitas Muhammadiyah Buton, Baubau, Indonesia \\ *Corresponding author. Email: tutie977@gmail.com
}

\begin{abstract}
Village financial management is one of the breakthroughs in village financial management towards community empowerment and it is to improve village development. The purpose of this study is to describe village financial management in empowering the community and to find out some of the factors that enable and hinder village financial management. This research applied qualitative descriptive research undertaken in Galanti village, Wolowa sub-district, Buton Regency, by interviewing and observing to obtain the data and information about village financial management interpreted into the village development program. The result indicated that financial management of Galanti village was the process of village financial management by implementing the planning, organization, coordination, and control of sources to achieve the goal effectively and efficiently, however, the imbalance still occurred in the process of community empowerment because the allocation of funds was concerned on physical development while the government was more dominant in planning activities and the distribution of village funds was not evenly distributed. The activities Community empowerment was prioritized for physical empowerment such as the construction of roads and clean water, while non-physical empowerment related to counselling, official training of the village government and PKK (Family Welfare Empowerment) was still less attention. The discussion revealed that the implementation of financial management to empower the community of Galanti Village was the need for village priorities and support for policies/regulations, outreaches, facilities and infrastructure. In this research, the implementation of village financial management towards community empowerment in Galanti village is an embodiment of the implementation of village allocation fund management to improve development programs effectively and efficiently.
\end{abstract}

Keywords: financial management, community empowerment, village fund allocation, village development

\section{INTRODUCTION}

The Village Act No. 6 of 2014 concerning Villages explains that Villages in 2015 will receive funding of $10 \%$ of the State Budget [1]. In the concept of Nawacita which is the current development priority program, it obtains one of the development priorities, namely developing Indonesia from the margin by strengthening regions and villages within a unitary state. Therefore, the issuance of The Village Act No. 6 of 2014 concerning Villages aims to create an independent village and optimally empower the village community related to the village potential concerned and the provisions governing the sources of village funds to organize the development is Government Regulation No. 60 of 2014 concerning funds villages as well as Government Regulation No. 43 of 2014 concerning regulations for implementing act no. 6 of 2014 concerning villages [2]. The purpose of granting village funds sourced from the State Budget is to be prioritized for development and community empowerment. Therefore, it might be interpreted that village funds deriving from the central government are not only prioritized for the development of village infrastructure but are also intended for the community empowerment. This is explained in Government Regulation No. 60 of 2014 concerning village funds sourced from the State Budget, in article 19 paragraph (2) it is explained that village funds as referred to in paragraph (1) are prioritized to finance development and empowerment of village communities. Galanti Village was one of the villages that received village funds from the State Budget. Village fund management starts from program planning, continues to the implementation after being held accountable [3].

Village financial management must certainly be organized well and accountably because the incoming funds of the village are not little funds, but they are enormous to be managed by the village government. By the Village Fund policy, the management dimension in implementing the Village Fund policy is required to organized properly because the public policy in it, occurs the design and planning process; implementation through various organizations and institutions; moreover, to achieve optimal results, the implementation of public policies must be controlled [3].

From the discussion above, it is obvious that good policy implementation it is also influenced by the good management process to achieve something expected when the policy implementation has been running. Based on 
Regulation of the Village Minister number 5 of 2015 concerning the determination of priorities for the use of village funds that the Empowerment of Village Communities is an effort to develop independence and prosperity of the community by increasing knowledge, attitudes, skills, behaviours, abilities, awareness, and utilizing resources through the determination of policies, programs, activities, and assistances in accordance with the essence of the problem and priority needs of the village community [4]. Empowerment refers to a series of actions organized systematically and reflecting the phases of activities or efforts to change a community that is lacking or powerless, powerful, and capable towards empowerment. The meaning of "obtaining" power, strength or ability refers to the initiative source in order to obtain or increase power, strength, or ability so that it has empowerment. The word "obtain" indicates that the source of the initiative for empowerment originates from the community itself. Therefore, the community must be aware of the need to acquire the ability of knowing. The meaning of the word "gift" shows that the source of the initiative is not from the community. Initiative to transfer power, capacity or strength are other parties who have power and ability, for example the government or other development agencies [5].

The Village Fund is a new policy for the Village itself. A lot of people doubt the success of this policy due to the unpreparedness of the Village Government Apparatus itself, especially in financial management which business process is almost the same as the level of the Regional Government. Basically, Effectiveness shows a measure of the level of compatibility between the results achieved and the results expected through the Village development planning document. It means that the main task of management is an effectiveness itself so that the preparation of the Village Medium Term Development Plan and the Village Government Work Plan will affect the effectiveness of the Village development program [6].

\section{RESEARCH METHOD}

This research obtained the primary data regarding the Village Fund Allocation policy in Galanti Village. Based on the available data, the researcher endeavoured to describe systematically, factually and accurately about the facts, properties and relationships in existing phenomena. The method used to analyse the data in this research was a descriptive qualitative method, a technique that described and interpreted the meaning of the data collected by paying attention to as many as possible aspects investigated at the time, so that the researcher obtained a general and overall picture of the actual situation. Data collection techniques were the most important step in the research, because the purpose of research was to obtain the data. Without knowing data collection techniques, it can be done by observation, interview, questionnaire, documentation, and a combination of the four [7].

\section{RESULTS AND DISCUSSION}

Based on the results of research conducted, researcher draws conclusion that the village development program in Galanti Village was effective, it referred to Village financial management as the implementation of the Village Fund policy for community empowerment, including:

\subsection{The implementation of the Village Fund policy was organized optimally and comprehensively by the Government of Buton Regency}

It was proved by the completeness of technical regulations further regulated by regulations at the regulation of Buton regent in providing guidance for the Village Government and was mandated by relevant Ministerial Regulations, such as the Ministry of Home Affairs of the Republic of Indonesia, the Ministry of Villages, the developing the underdeveloped Regions and Transmigration, and the Ministry of Finance of the Republic of Indonesia.

\subsection{Village financial management was organized optimally}

This was proved by the reporting of the realization in Village Fund use and village development planning documents to the Regent through the sub-district head. It was explained that to realize accountability through administrative, technical and financial accountability made by the Implementers of Village Government Policy as accountability documentation was requested for inspection or certain purposes because the managed budget was the State budget. The results of the field study showed that the Village development program was influenced by the implementation of the Village Fund policy and Village financial management that financial management could be organized if the planning in compiling organizational goals was formulated in a quality manner, organizational structure and work procedures were arranged properly so that the implementation of tasks was in accordance with the organizational structure that had been set, the Policy Implementers organized their duties in accordance with their respective duties and functions prepared earlier, budgeting on goods/services expenditure in accordance with the planned program/activity as well as the work program presented in the activity report in accordance with the work program in the planning.

\subsection{The use of the Village Fund}

The use of the Village Fund refers to the List of Proposed Activity Plans and work plan and budget which each community empowerment agency received related to the needs of the work program like the operational costs of the Village Government, include: 
then signed by the Village Head as the person in charge of

\subsubsection{Operational Costs of the village consultative agency}

Operational Costs of the village consultative agency, the amount was determined based on the Village Budget Credit of each village of Rp. 8,506,700, it was paid for:

a. Office stationary Procurement

b. Meeting fee

c. Official travel expenses

\subsubsection{Operational costs of the village community empowerment agency}

Operational costs of the village community empowerment agency, a maximum Rp 2,381,900 per year, were paid for:

a. Office stationary Procurement

b. Meeting fee

c. Official travel expenses.

\subsubsection{Supporting Family welfare empowerment of activities}

Supporting Family welfare empowerment of activities in Village amounting Rp 3,969,700, - was paid for activities:

a. Secretariat

b. Direct expenditure

c. Office stationary fee

d. Official travel expenses

\subsubsection{The operational costs of Youth Organization}

The operational costs of Youth Organization of $\mathrm{Rp}$ 1,984,900 are used for:

a. Office stationary Procurement

b. Meeting fee

c. Official travel expenses

Village Financial Management in Galanti was planned according to Regulation of Regent and discussed in the meetings of village consultative agency with the Village Government. The implementation of the Allocation of village funds program was related to the List of Proposed Activity Plans and work plan and budget, moreover, it was accounted for by each village/community institution. Village development plans ensured interrelation and consistency between planning, budgeting, implementation and supervision. One of the objectives of village development plans was to realize village development based on community needs and local conditions [8]. Local Government work plan aims to prepare activity proposal list that are new, rehab and continuation of development activities to be reported to regents / mayors through the subdistrict head as the basic material of district government work plan and prepare annual village activity proposal list to be budgeted in the village government budget. List of Proposed Activity Plans was verified by the guiding team, the activity. The List of Proposed Activity Plans signed was conveyed to the sub-district head for approval and then returned to the village head. After everything was completed, a Village Regulation on the Village Budget was stipulated, which included a Work Plan and Budget document for activities funded by the Village Fund Allocation program. From the Work Plan and Budget of Galanti Village in 2018, it stated that the utilization of the allocation of village funds in the physical development program was realized through the construction of river stone channels, as evidenced by the minutes explained that the first party namely the village government was handed over allocation of village funds.

Based on the research, it showed that the financial management of Galanti Village was quite good and significant because it was increasing from year to year. Planning, implementation, and accountability were based on the List of Proposed Activity Plans and work plan and budget. The village development work plan by referring to the Medium-term development plan of village was prepared by the village work plan and budget (stipulated by a Village Regulation). The physical development was undertaken well, from the administration, it was based on the rules and regulations. The village community participated in village development, but in the community empowerment of Dapurkejambon in the training program there was very little interest from the community.

\section{CONCLUSION AND SUGGESTION}

Accountability of the allocation of village funds both technically and administratively was organized based on the applicable regulations with evidence of accountability in a transparent and accountable manner.

The Government of Galanti Village was responsible for managing the allocation of village funds properly in accordance with existing regulations, this was evidenced by the existence of a Liability Report, which contains a cash ledger, receipts, and other activities. The realization report and the accountability report on the implementation of the Village Budget and Income were informed to the public in writing and with media information that was easily accessible by the community. The Galanti Village Work Plan and Budget of 2018 that utilized the allocation of village funds in physical development programs was realized through village development, as evidenced by the implementation of the construction completed. Village financial management in accordance with the Planning, implementation, accountability of development and empowerment of the village of Galanti was organized by the village government in accordance with existing regulations, as evidenced by the stages of activity planning, preparations could be made in the form of compiling a Proposed Activity Plan and Budget Work Plan whose activities were funded by the Village Fund Allocation. However, the purpose of Village Financial Management in increasing community empowerment in Galanti Village was optimal but the community lacks good participation. 


\section{REFERENCES}

[1] Kemenkum HAM, "UU RI Nomor 6 Tahun 2014," no. Desa, 2014.

[2] “pp_8_2016_ttg-perubahan-kedua-atas-pp60_2014.pdf.".

[3] Y. Hulu, R. Harahap, and M. Nasutian, "Pengelolaan Dana Desa dalam Pemberdayaan Masyarakat Desa," JUPIIS J. Pendidik. ILMU-ILMU Sos., vol. 10, p. 146, Jun. 2018.

[4] A. Sadat, "Pemberdayaan Masyarakat Nelayan Dalam Pengelolaan Sumber Daya Alam Laut Terhadap Peningkatan Ekonomi Yang Berkelanjutan Di Desa

Kakenauwe Dan Desa Wagari Kecamatan Lasalimu,” J. Pengabdi. Kpd. Masy. MEMBANGUN NEGERI, 2019.

[5] L. N. Nafidah and M. Suryaningtyas, "Akuntabilitas Pengelolaan Alokasi Dana Desa Dalam Upaya Meningkatkan Pembangunan Dan Pemberdayaan Masyarakat," BISNIS J. Bisnis dan Manaj. Islam, vol. 3, no. 1, p. 214, 2016.

[6] Z. Peja, "Financial Management In Economic Growth Of Transition Countries : In Kosovo Will Be Special Baki Koleci Menaxhimi Financiarë Në Rritje Ekonomike Të Vendeve Në Tranzicion : Në Theks Të Veçantë Kosova Baki Koleci Universiteti ' Haxhi Zeka ' - Pejë baki.kole," vol. 28, pp. 165-170, 2018.

[7] P. D. Sugiyono. Metode penelitian kuantitatif, kualitatif, dan R\&D. 2016.

[8] I. Beazley, Financial Management in Government: Insights on Skills Development, vol. 18, no. 3. 2019. 